Enallagma exsulans, Sherborn, Dover, and Medfield, Mass.; new to the State with the above records.

Enallagma ebrium, Brattleboro, Vt.; new to the State.

Amphiagrion saucium, Montgomery, Vt.; new to the State (see above).

Cordulegaster diastatops, Jay and Troy, Conn.; new to the State with Mr. Woodruff's records.

Boyeria vinosa, Wolcott, Vt., July 23; new to the State.

Libellula auripennis, Niantic, Conn., August 8; new to the State. Sympetrum rubicundulum, Newport, Vt.; new to the State (see

ibid., Part I).

Sympetrum semicinctum, North Haven, Conn.; new to the State. Erythrodiplax berenice, Niantic and Stamford, Conn.; new to the State (see ibid., Part I).

The following record is represented by a specimen in the Boston Society of Natural History:

Erythrodiplax berenice (Drury), Barrington, L. I., June; new to the State.

Species known to Maine $=99$.

Species known to New Hampshire $=97$.

Species known to Vermont $=26$.

Species known to Massachusetts $=123$.

Species known to Rhode Island $=27$.

Species known to Connecticut $=72$.

\title{
SOME VARIATIONS IN THE GENUS VANESSA (PYRAMEIS.)
}

\section{By Fordyce Grinneld, Jr.}

The following notes on some very significant variations of the species of Vanessa (Pyrameis), originated from a series found in the collection of Mr. James E. Cottle of San Francisco. Other specimens, also representing the same variations, are in the collections of Mr. J. D. Graves of Oakland, Mr. J. C. Huguenin of San Francisco, and a few from the writer's collection have been deposited with the series in Mr. Cottle's collection. The illustration represents those in Mr. Cottle's collection and captured by him. 


\section{Vanessa (Pyrameis) caryæ Hübner.}

This species is well known in its typical form as figured by Holland, Wright, Letcher and Essig. Its range extends along the Pacific Coast from Vancouver and British Columbia to Chili, being especially abundant in California. It is recorded in Skinner's Catalogue from “Ariz., Nev., Utah," but I have seen no specimens from these regions, and do not know of any authentic records. Nor have I seen any specimens from the western coast of South America, where a knowledge of the variations would be of particular interest in the evolutionary study of the species. The species varies in size but there seems to be no correlation between the size and marking variation. The normal or typical caryo seems to be characterized especially by the extent of the black markings of the primaries and the large submarginal black eye spots of the secondaries, only slightly pupilated with bluish scales, not white.

\section{Vanessa caryæ var. muelleri Letcher.}

This variation as described by Letcher (4) varies from the normal form of caryox, which is the commonest, in the extension of the fulvous color of the basal portion of the forewings and the nearly complete elimination of the black markings in this area. The apical white spots develop into dashes extending towards the outer margin. The large fulvous spot or series of spots in the costo-apical black field is still present. There is an additional large fulvous patch or two patches (usually) just below the row of apical white spots. The black marginal band is connected with the costo-apical black area by a rather broad black area. On the secondaries the black encircled blue spots become white or bluishwhite, and there is a slight extension of the black in the upper portion. The specimens figured by Essig are not this but belong to the following variation.

Of the typical muelleri variation I have seen specimens from the following Tocalities:-LaFayette Square, San Francisco, August 1914 (Cottle); Los Angeles, July 1915 (Karl Skolfield); 18th Street Square, San Francisco, October 8, 1917 (Huguenin); San Francisco, October 17, 1917 (Huguenin).

\section{Vanessa caryæ var. intermedia var. nov.}

This intermediate variety between the typical caryo and typical muelleri differs in having basal traces or remnants of the black 
markings in the fulvous replacement of the forewings; and a broad black band on the upper half of the outer margin of the hindwings. It still keeps the row of black-encircled blue-centered eye spots on the hindwings. The larger fulvous spot below the apical row of white spots is large. The fulvous patch in the costo-apical black area is still present. I have before me three specimens from the following places:-Berkeley, August 3, 1917 (Graves); November 5, 1911 (Graves); San Francisco (Cottle); San Francisco, October 10, 1917 (Huguenin).

\section{Vanessa caryæ var. letcheri var. nov.}

The striking difference from muelleri lies in the entire disappearance of the fulvous spots or band of spots in the costo-apical black area, leaving a solid black, quadrangular area. The two fulvous patches below the apical row of white spots are much larger, and nearer the larger, basal fulvous area, leaving only a narrow black connection to the quadrangular black area and wider black outer margin. The basal portion of the hindwings is blacker than in muelleri. The following specimens have been examined:-Castella, Shasta Co., June 1913 (Cottle); Berkeley, July 20, 1917 (Graves); July 30, 1917 (Graves); Los Angeles, July 1915 (Harold Burkhardt); Los Angeles, July 1915 (Karl Skolfield); 18th Street Square, San Francisco, September 24, 1917; Oakland, September 4, 1917; October 9, September 17 (Huguenin).

In all these variations the black discal dash in the costal side of the large fulvous area of the primaries remain practically unchanged; all the other markings become more or less altered.

In 1898 the variety letcheri was apparently not known in collections and the variety muelleri was "very rare," but Letcher mentioned the fact that Mueller had some intergrades between carye and muelleri in two directions; one is like the one here named intermedia, and the other with the blue spots of the secondaries replaced by white and without any change in the primaries. The apical white spots are either blurred, smaller, or lengthened out in the direction of the apex, and indefinite. These remarkable and significant variations seem to be increasing and tending in the direction of letcheri. Letcher recorded the variations known to him as taken only in the fall, but they are now known to be found throughout the year. 
As Letcher surmises, in the case of muelleri, this variation may be "an example of the evolution of a true variety time only will tell." At any rate since 1898 the variations have become more common, letcheri the commonest, and are very suggestive from an evolutionary standpoint. We must watch the behavior of these variations still more in future years.

Essig (1) figures two specimens of letcheri as muelleri. Here we have a series extending from typical caryo, through intermedia and muelleri to letcheri, showing a progressive evolution. $\mathrm{Mr}$ Cottle took two other specimens of caryo in Lafayette Square, San Francisco, showing an interesting variation, but they do not belong in the same category as the above variations. One of these has the primaries of the usual light coral red color, while the hindwings are of a light coral pink or a washed-out appearance. The other specimen has the usual color of all the wings replaced by a light flesh-pink (Ridgway).

\section{Vanessa cardui Linn. var.}

Expanse $66 \mathrm{~mm}$. This very striking variation of a cosmopolitan butterfly bears a very close resemblance to letcheri, as can be seen, and is very nearly like that of cardui figured by Newman (5) from England. There is a submarginal row of comparatively large white spots on the primaries, the two middle ones being the largest; also a similar row of white spots on the secondaries which are of the same size. The outer ends of the veins of the hindwings are bordered wholly with black. And the middle region of the hindwings is of the same fulvous color as the ground color of letcheri.

Now cardui is a cosmopolitan butterfly while carye is restricted to the Pacific side of the two Americas, and the most restricted of all the Vanessas (Pyrameis); but here we have a form which occurs in cardui of the same pattern as the seemingly more recent one in caryo. These sports, aberrations, or what is better to call them, variations of a different degree, are of more significance in the evolutionary history of species than seems to be generally supposed. We have here, probably, a good example of orthogenetic variation or a definitely directed evolution.

Vanessa atalanta Linn. var. edwardsi var. nov.

Expanse $56 \mathrm{~mm}$. The wide band or series of quadrate spots across the primaries is an apricot-orange (Ridgway) instead of a 
carnelian red as in typical atalanta and the costo-apical or subapical white patch of atalanta is a salmon-buff in this variety. There are four white apical spots. The outer margin of the hindwings are of an apricot-orange; the basal portion of the primaries and secondaries is of a bordeaux red (rusty red) instead of a deep purplish black as in atalanta. There is a submarginal row of black spots onthe hindwings in the same position as those of carye. The underside more nearly resembles atalanta. In its characters this variation partakes of the aspects of both carye and atalanta. Henry Edwards (3) records a specimen of what he speaks of as a hybrid between carye and atalanta. The description of his specimen resembles mine very closely. The submarginal row of spots had white pupils while mine has none, except a very faint trace in two of them. Henry Edwards' specimen was raised by Dr. Behr from the larva from Lagunitas, Marin Co., July 1876; while Mr. Cottle's specimen was ćaught flying at Buchanan and Washington Streets, San Francisco, in August 1914. So there is quite a time interval in the capture of these two similar variations, but in a short distance geographically. This is a very interesting variation, which we are hardly justified in calling a hybrid, and undoubtedly has some evolutionary significance.

As an excuse or an explanation for naming these new variations it is well to say that it is particularly useful to know as much about the variations of a species as possible, especially now, when so much is being said of the order of evolution; whether it is indiscriminate or directed or whether it may follow both paths. It is only by the accumulation of definite data concerning variations that we can arrive at a correct idea of the order of evolution in a given species. It is the method we want to know, and there is no more intricate problem confronting us.

\section{REFERENCES.}

1. Essig, E. O. The Genus Vanessa in California. Pomona Journal Entom. and Zoöl., VIII, 3, Sept. 1916, pp. 97-108, fig. 1-11.

2. Wright, W. G. The Butterflies of the West Coast, 1905, pp. 177-178, pl. XXII.

3. Edwards, Henry. Proc. California Acad. Sci. (Pacific Coast Lepidoptera), Vol. 7, 1877, pp. 171-172. 
4. Letcher, Beverly. Variation of Pyrameis caryo Hübner. Entom. News, IX, 2, p. 38, pl. III, Feb. 1898.

5. Newman, Edward. An Illustrated Natural History of British Butterflies and Moths. London, p. 64, fig. 17, var. 1.

\section{Explanation of Plate.}

1. Vanessa carye var.

2. Vanessa carye var.

3. Vanessa atalanta var. edwardsi $\mathrm{n}$. var.

4. Vanessa cardui var.

5. Vanessa carye normal.

6. Vanessa carye var. intermedia var. nov.

7. Vanessa carye var. muelleri Letcher.

8. Vanessa carye var. letcheri $\mathrm{n}$. var. 

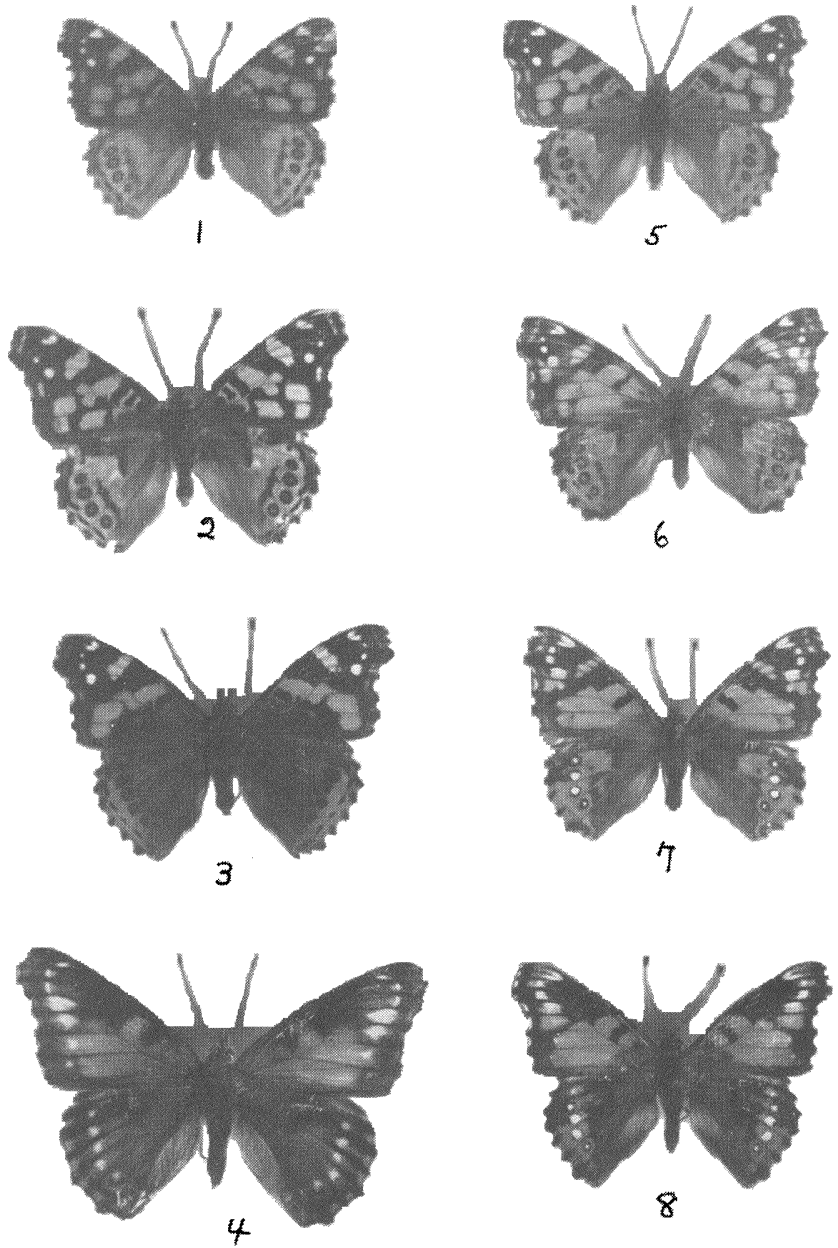

Grinneli-Variations in the Genus Vanessa. 

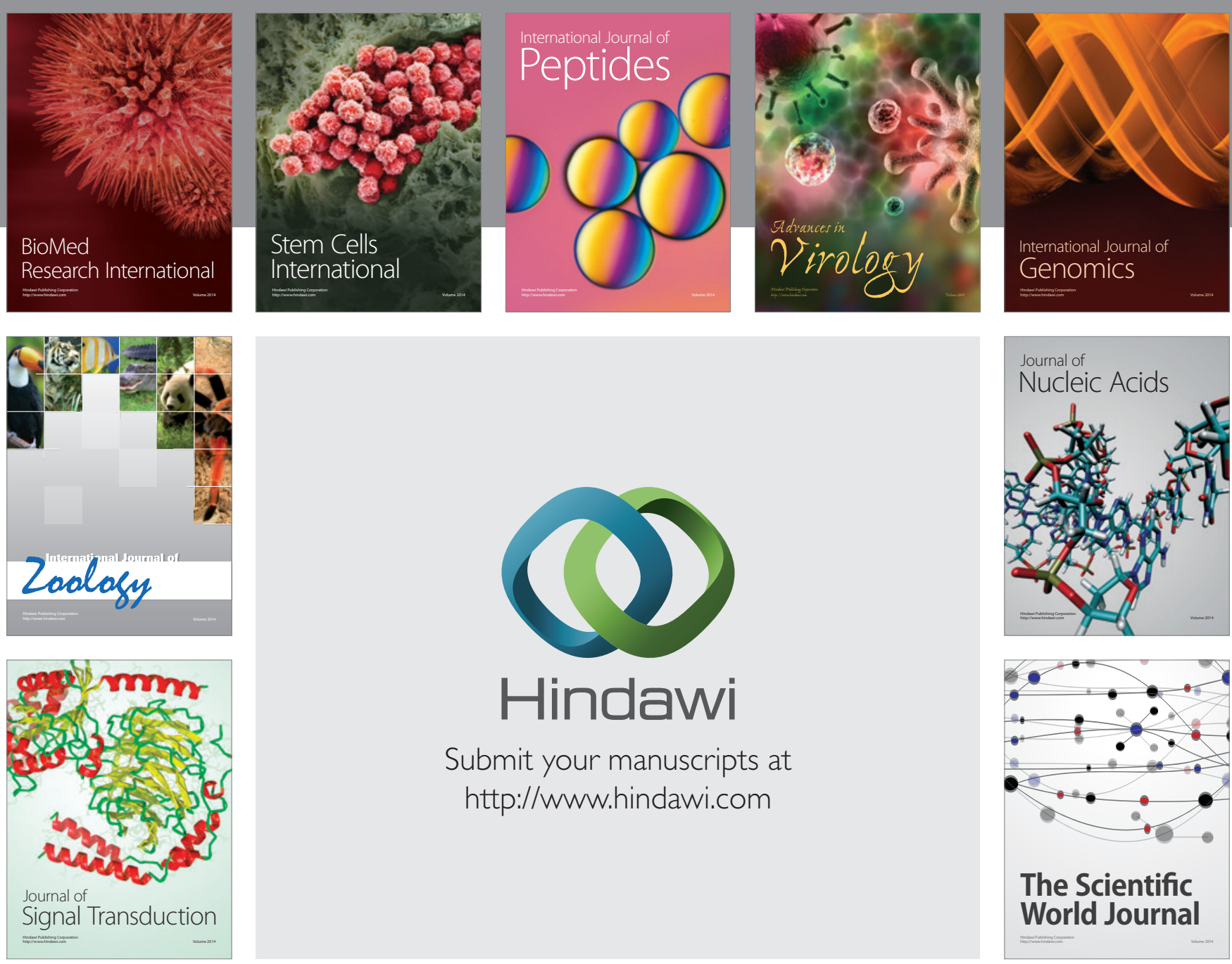

Submit your manuscripts at

http://www.hindawi.com
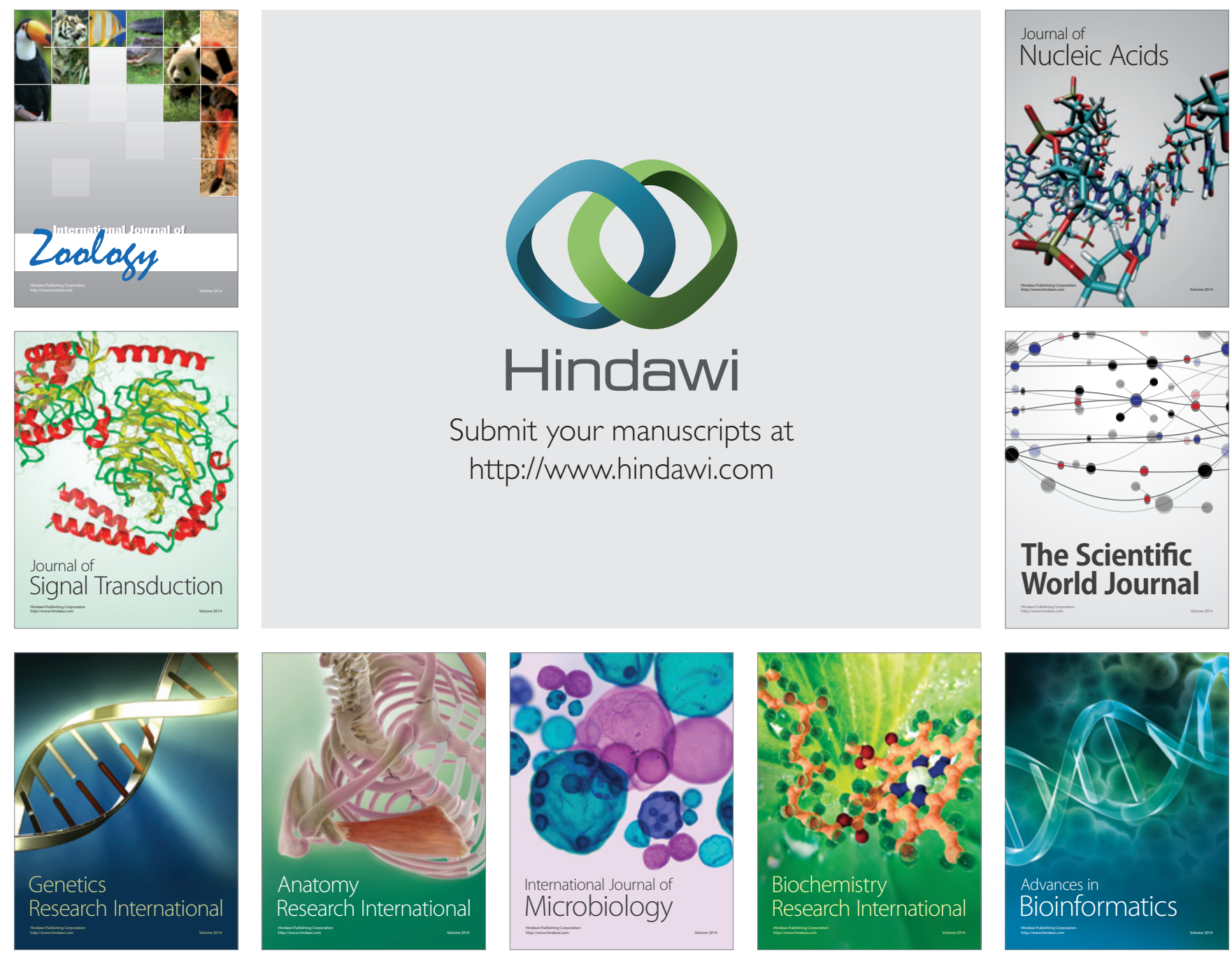

The Scientific World Journal
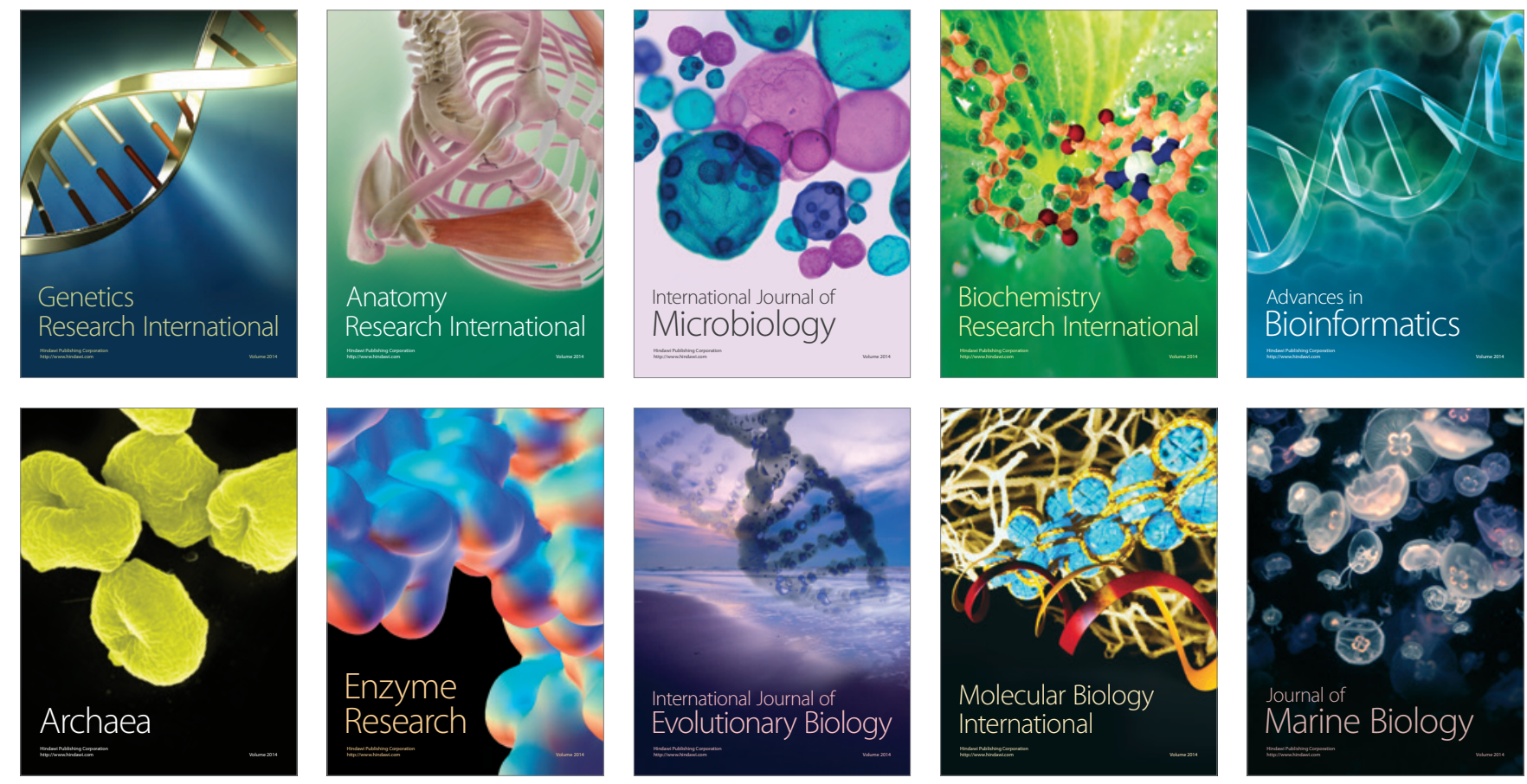